\title{
ANALISIS STRATEGI DAN PROGRAM PENINGKATAN DAYA SAING PADA INDUSTRI UNGGULAN PROVINSI JAWA TENGAH DALAM MENGHADAPI MASYARAKAT EKONOMI ASEAN (MEA)
}

\author{
Puspita Tri Jayanti, Masyhudi Muqorobin
}

\author{
Program Studi Ilmu Ekonomi dan Studi Pembangunan \\ Fakultas Ekonomi dan Bisnis Universitas Muhammadiyah Yogyakarta \\ Email Korespondensi: Puspitatj26@gmail.com
}

Naskah Diterima: Januari 2017; Disetujui: April 2017

\begin{abstract}
The establishment of ASEAN Economic Community (AEC), forces industries in Central Java Province shall retain their high level of competitiveness. This study aims to know what kind of industry that can be categorized as leading industry through $S L Q, D L Q$, combination of the methods and the Shift Share analysis. In addition, this study investigates on how much the level of competitiveness that recently retained by every leading industry in Central Java Province, either national or ASEAN level through RCA. Finally, this study helps to formulate strategy to increase and intensify the competitiveness due to the AEC through SWOT Balanced Scorecard analysis. The result showed that, there are industry in Cental Java Province which is included as a leading industy, such as beverage, some agriculture products, manufacturing industries, printing and reproduction of recorded media. There are some Industries that are competitive either national or ASEAN level such as apparel, timber, wood, printing and reproduction of recorded media. While textile and furniture have a level of competitiveness at national level only. The strategy to improve industrial competitiveness in the face of AEC namely SO Strategy to expand the non traditional's export; ST Strategy to improve the quality of product; WO Strategy by enhancing the quality of skilled human resources to meet market demand; WT Stategy by providing incentivies to industries that are able to perform and increase proportion of raw materials. Firm equity, organizational capital and human capital are ways to do the program of improving industrial competitiveness to welcome AEC.
\end{abstract}

Keywords: competitiveness, leading industry, SWOT balanced scorecard analysis

JEL Classification: D41, L10, B40

Abstrak: Berdirinya Komunitas Ekonomi ASEAN (MEA), mengaharuskan setiap jenis industri di Provinsi Jawa Tengah memiliki dan mempertahankan tingkat daya saing yang tinggi. Studi ini bertujuan untuk mengetahui jenis industri yang dapat dikategorikan dalam industri unggulan melalui $S L Q, D L Q$, kombinasi keduanya serta analisis Shift Share untuk keunggulan kompetitif. Studi ini juga bertujuan untuk mengetahui seberapa besar tingkat daya saing yang baru-baru ini dipertahankan oleh setiap industri terkemuka di Propinsi Jawa Tengah, baik tingkat nasional maupun ASEAN melalui RCA. Terakhir, studi ini bertujuan untuk mencari strategi yang sesuai untuk meningkatkan dan mengintensifkan daya saing karena MEA melalui analisis SWOT Balanced Scorecard. Hasil penelitian menunjukkan bahwa ada industri di Propinsi Jawa Tengah yang termasuk sebagai industi unggulan. Diantaranya adalah, minuman, pengolahan tembakau, tekstil, pakaian jadi, kayu, kayu, percetakan dan reproduksi media rekaman, furnitur, dan industri manufaktur lainnya. Jenis Industri yang memiliki keunggulan baik di tingkat nasional maupun ASEAN adalah pakaian jadi, kayu, serta percetakan dan reproduksi media rekaman. Sementara tekstil dan furnitur hanya memiliki tingkat daya saing di tingkat nasional saja. Strategi untuk meningkatkan daya saing industri dalam menghadapi MEA yaitu strategi SO untuk memperluas ekspor non tradisional; strategi ST untuk meningkatkan kualitas produk; strategi WO dengan meningkatkan kualitas sumber daya manusia yang terampil guna memenuhi permintaan pasar; strategi WT untuk memberikan insentif kepada industri yang mampu melakukan dan meningkatkan proporsi bahan baku. Ekuitas perusahaan, modal organisasi dan sumber daya manusia adalah strategi untuk melakukan program peningkatan daya saing industri dalam menghadapi ASEAN Economic Community

Kata kunci: daya saing, industri unggulan, analisis SWOT balanced scorecard

Klasifikasi JEL: D41, L10, B40 


\section{PENDAHULUAN}

Di era globalisasi saat ini, tingkat daya saing menjadi tolak ukur yang wajib dimiliki dalam mewujudkan persaingan pasar bebas baik dalam kegiatan maupun perdagangan ekonomi dunia yang menjadi pokok dari kekuatan pasar. Perkembangan pada tingkat daya saing baik dalam skala nasional maupun internasional tidak akan terlepas dari daya saing di tingkat regional. Deklarasi ASEAN Concord II diselenggarakan pada tahun 2003.

Para petinggi ASEAN menyepakati pembentukan Masyarakat ASEAN 2020 yang mengandung tiga pilar, yakni Masyarakat Politik dan Keamanan ASEAN, Masyarakat Sosial dan Budaya ASEAN, serta Masyarakat Ekonomi ASEAN. Namun di tahun 2007, para petinggi ASEAN sepakat untuk melakukan percepatan realisasi pilar yang ketiga yaitu Masyarakat Ekonomi ASEAN (MEA) pada tahun 2015. Dimana para petinggi ASEAN sepakat jika proses integrasi ekonomi regional dipercepat melalui Cetak Biru (Blue Print) Masyarakat Ekonomi ASEAN di tahun 2007 dengan begitu, program MEA pada tahun 2015 dapat terlaksana.

Pada tahun 2014, Indonesia menduduki peringkat 34 dan turun menjadi peringkat 37 pada tahun 2015. Terdapat kesenjangan dalam daya saing yang cukup lebar antara negaranegara kawasan ASEAN lain seperti Singapura yeng menduduki peringkat dua, Malaysia pada peringkat 18 serta Thailand pada peringkat 37 . Peringkat daya saing tersebut diukur dengan menggunakan beberapa indikator yang telah ditentukan oleh World Economic Forum yaitu pengelolaan institusi secara tepat, kondisi dan situasi makro, pembangunan infrastruktur, kondisi dan situasi makro, pendidikan atas pelatihan, kesehatan dan pendidikan dasar, efisiensi pasar maupun tenaga kerja, pengembangan pasar uang, skala pasar, lingkungan bisnis dan inovasi, serta kesiapan teknologi. Maka dibutuhkan penelitian yang bersifat sektoral pada setor prioritas MEA seperti industri.

Pada tahun 2013 daya saing Indonesia berada pada peringkat empat. Peringkat tersebut dapat berimplikasi pada rendahnya tingkat daya saing produk industri dalam negeri yang rendah, sedangkan produk industri negara seperti Singapura, Malaysia, dan Thailand yang memegang peringkat tiga besar dalam tingkat daya saing industri. Tiga negara tersebut dapat dengan mudah mengambil alih pasar domestik. Rendahnya tingkat daya saing Indonesia dapat dilihat dari rendahnya peringkat ekspor manufaktur per kapita dimana Indonesia menempati peringkat ke-tujuh, begitu juga dengan sumbangan ekspor manufaktur terhadap total ekspor yang menduduki peringkat yang sama. Hal ini yang memperkuat pernyatan bahwa tingkat daya saing di Indonesia masih rendah di negara ASEAN.

Daya saing di tingkat nasional tidak lepas dari pengaruh daya saing tingkat regional. Peringkat pertama daya saing provinsi di Indonesia diduduki oleh DKI Jakarta dengan skor 3,3580, sedangkan Jawa Tengah menduduki peringkat ke empat di tahun 2014 naik satu tingkat dari tahun 2013. Menurut Alisjahbana (2014), koridor ekonomi yang mempunyai potensi industri nasional adalah koridor Pulau Jawa. Hal tersebut dipengaruhi oleh jumlah industri yang berkembang di koridor tersebut.

Pada tahun 2012-2014, Provinsi Jawa Tengah memiliki net ekspor terendah kedua setelah DKI Jakarta, hal ini disebabkan karena jumlah ekspor di Jawa Tengah lebih sedikit dibandingkan dengan jumlah impor yang berimplikasi pada defisit neraca perdagangan yang besar di Jawa Tengah. Dengan rendahnya tingkat daya saing tersebut, perlu untuk melakukan kajian ulang mengingat telah berlangsungnya program MEA. 
Jika tidak dilakukan evaluasi ataupun kajian mengenai tingkat daya saing di Provinsi Jawa Tengah maka peluang keuntungan yang dapat diperoleh oleh produsen, konsumen, ataupun perekonomian secara keseluruhan maka tidak akan bisa dirasakan manfaatnya secara optimal. Dengan demikian peningkatan daya saing industri di Provinsi Jawa Tengah dinilai sebagai hal yang penting mengingat program MEA telah berlangsung.

Peningkatan daya saing pada sektor industri pengolahan yang merupakan salah satu penghasil ekspor haruslah diupayakan perkembangannya, dengan cara menjadikan sektor industri pengolahan di Provinsi Jawa Tengah menjadi prioritas perdagangan pada pasar tunggal MEA. Pemerintah Provinsi Jawa Tengah akan bertekad dalam mengembangkan kemampuan ekspornya. Sehubungan dengan uraian di atas maka peneliti mengajukan penelitian menegenai "Analisis Strategi dan Program Peningkatan Daya Saing Pada Industri Unggulan Provinsi Jawa Tengah dalam Menghadapi Masyarakat Ekonomi ASEAN (MEA)".

Berdasarkan permasalahan yang terjadi, maka penelitian ini dirumuskan dalam bentuk pertanyaan sebagai berikut:

1. Apa jenis industri yang menjadi produk unggulan di Provinsi Jawa Tengah?

2. Apa jenis industri yang memiliki keunggulan kompetitif di Provinsi Jawa Tengah?

3. Bagaimana kondisi daya saing untuk industri unggulan di Provinsi Jawa Tengah dalam rangka menghadapi MEA?

4. Apa strategi yang digunakan untuk meningkatkan daya saing industri unggulan di Provinsi Jawa Tengah dalam rangka menghadapi MEA?

5. Apa program strategis yang akan dibuat dalam rangka meningkatkan daya saing industri unggulan di Provinsi Jawa Tengah dalam menghadapi MEA?

\section{METODE PENELITIAN}

\section{Analisis Static Location Quotient (SLQ)}

Menurut Warpani (1980), analisis Static Location Quotient (SLQ) merupakan analisis permulaan untuk mengetahui keunggulan suatu daerah dalam sektor kegiatan tertentu. Secara matematis dapat dirumuskan pengukuran untuk nilai SLQ yaitu:

$$
S L Q=\frac{Y x j / Y j}{Y x i / Y i}
$$

\section{Keterangan:}

SLQ = Nilai SLQ

$\mathrm{Yxj}=$ Nilai output industri $\mathrm{x}$ di provinsi Jawa Tengah

$Y_{j} \quad=$ Nilai jumlah output industri di Provinsi Jawa Tengah

Yxi = Nilai output industri $x$ di Indonesia

$\mathrm{Yi}=$ Nilai jumlah output industri di Indonesia

Terdapat tiga kemungkinan nilai dari koefisien SLQ yang berkisar antara nol sampai dengan positif tak terhingga yaitu:

a. Nilai dari koefisien SLQ kurang dari satu menunjukkan bahwa sektor tersebut tidak mempunyai keunggulan komparatif.

b. Nilai dari koefisien SLQ sama dengan satu menjelaskan bahwa sektor tersebut mempunyai keunggulan relatif yang sama dengan rata-rata semua wilayah.

c. Nilai koefisien SLQ yang nilainya lebih besar dari satu menunjukkan bahwa sektor tersebut memiliki keunggulan komparatif yang nilainya lebih tinggi dari rata-rata wilayahnya.

\section{Analisis Dynamic Location Quotient (DLQ)}

Analisis Dynamic Location Quotient (DLQ) mampu memberikan solusi pada kelemahan yang terjadi pada analisis SLQ dengan cara, membandingkan laju pertumbuhan suatu sektor provinsi dengan laju pertumbuhan sektor tersebut di level yang lebih tinggi lagi yakni 
nasional. Secara matematis, dapat dirumuskan alat untuk menghitung nilai DLQ dengan rumus sebagai berikut:

DLQxj $=\left[\frac{(1+\mathrm{gxj}) /(1+\mathrm{gj})}{(1+\mathrm{Gxi}) /(1+\mathrm{Gi})}\right] \mathrm{t}=\frac{\text { IPPIxj }}{\text { IPPIxi }}$

Dengan

$g(G)=\left(\frac{Y t}{Y 0}\right)^{\frac{1}{t}}-1$

Keterangan:

DLQxj : Indeks potensi pada industri $x$ untuk Provinsi Jawa Tengah

Gxj : Pertumbuhan nilai keluaran (output) industri $x$ untuk Provinsi Jawa Tengah

gj : Jumlah rata-rata pertumbuhan nilai keluaran (output) untuk seluruh industri Provinsi Jawa Tengah

Gxi : Pertumbuhan nilai keluaran (output) industri $x$ di Indonesia

Gi : Jumlah rata-rata pertumbuhan nilai keluaran (output) untuk seluruh industri di Indonesia

T : Selisih antara tahun akhir 2014 dan tahun awal 2010

Yt : Nilai keluaran (output) untuk tahun 2014

Y0 : Nilai keluaran (output) pada tahun 2010

IPPIxj : Indeks potensi pengembangan industri $x$ untuk Provinsi Jawa Tengah

IPPIxi : Indeks potensi pengembangan industri $x$ untuk Indonesia

Terdapat tiga kemungkinan nilai dari koefisien DLQ yang dapat diartikan yaitu; apabila koefisien DLQ lebih dari satu, artinya potensi pertumbuhan industri $x$ di Provinsi Jawa Tengah lebih maju jika dibandingkan dengan industri $x$ di Indonesia. Namun, apabila koefisien DLQ kurang dari satu, maka potensi pertumbuhan untuk industri $x$ di Provinsi Jawa Tengah kurang maju jika dibandingkan dengan industri $x$ di Indonesia.

\section{Analisis Gabungan SLQ dan DLQ}

Dari penjelasan mengenai analisis SLQ dan DLQ kemudian peneliti dapat mengidentifikasi industri unggulan di Provinsi Jawa Tengah. Gabungan koefisien SLQ dan DLQ akan menjadi pedoman untuk menentukan apakah suatu industri termasuk ke dalam kriteria unggulan, prospektif, andalan, maupun tertinggal. . Untuk menentukan kriteria unggulan digunakan matriks sebagai berikut:

\begin{tabular}{|c|l|l|}
\hline DLQ & \multicolumn{1}{|c|}{ SLQ $>1$} & \multicolumn{1}{|c|}{ SLQ $<1$} \\
\hline DLQ $>1$ & $\begin{array}{l}\text { Industri } \\
\text { Unggulan }\end{array}$ & $\begin{array}{l}\text { Industri } \\
\text { Andalan }\end{array}$ \\
\hline DLQ $<1$ & $\begin{array}{l}\text { Industri } \\
\text { Prospektif }\end{array}$ & $\begin{array}{l}\text { Industri } \\
\text { Tertinggal }\end{array}$ \\
\hline
\end{tabular}

\section{Analisis Shift Share}

Analisis Shift Share adalah analisis yang digunakan untuk mengetahui sektor ekonomi yang termasuk ke dalam bagian dari sektor yang mempunyai keunggulan kompetitif atau dengan kata lain, sektor yang mampu berkompetisi dengan sektor sejenis di wilayah lain. Analisis ini bertujuan untuk menentukan kinerja maupun produktifitas pada ekonomi regional dengan membandingkan ke level yang lebih tinggi. Nilai keunggulan kompetitif dapat diukur dengan menggunakan rumus sebagai berikut:

$$
\begin{aligned}
\mathrm{K} x \mathrm{j}= & Y x j(\mathrm{rxj}-\mathrm{rxi}) \\
& \text { Dengan } \\
r x j= & \left\{\frac{\left(Y x j-Y^{*} x j\right)}{Y^{*} * x j}\right\} \times 100 \\
r x i= & \left\{\frac{\left(Y x i-Y^{*} x i\right)}{Y^{*} * x i}\right\} \times 100
\end{aligned}
$$

Keterangan :

Cxj : Nilai keunggulan kompetitif

Yxj : Nilai keluaran (output) industri x di Provinsi Jawa Tengah tahun 2014

$Y^{*} \times j \quad$ : Nilai keluaran (output) industri $x$ di Provinsi Jawa Tengah tahun 2010

Yxi : Nilai keluaran (output) industri $x \mathrm{~d}$ Indonesia tahun 2014 
$Y^{*} \mathrm{xi} \quad$ : Nilai keluaran (output) industri $\mathrm{x} \mathrm{di}$ Indonesia tahun 2010

rij : Perkembangan industri $x$ di Provinsi Jawa Tengah dari tahun 2010 -2014

rx $\mathrm{i} \quad$ : Perkembangan industri $x$ di Indonesia dari tahun 2010 - 2014

Terdapat dua ketentuan pada penilaian keunggulan kompetitif yaitu; (1) apabila nilai Cxj menunjukkan angka positif, artinya terdapat keunggulan kompetitif pada komoditas tersebut; (2) Apabila nilai Cxj menunjukkan angka negatif yang artinya tidak terdapat keunggulan kompetitif pada komidtas tersebut.

\section{Analisis RCA}

Menurut Tambunan (2001), Metode RCA merupakan metode untuk mengetahui komoditas apa yang mempunyai keunggulan atau yang memiliki tingkat daya saing ekspor di suatu daerah terhadap dunia. Nilai RCA dapat diukur menggunakan rumus :

$$
\mathrm{RCA}=\frac{X x j / X x i}{X j / X i}
$$

Dimana:

RCA : Nilai RCA

$\mathrm{Xxj} \quad$ : Nilai ekspor untuk industri $x$ di negara $j$

$X_{j} \quad$ : Nilai total ekspor untuk negara $j$

Xxi : Nilai ekspor untuk industri $x$ dunia

Xi : Nilai total ekspor dunia

Nilai RCA berkisar dari nol sampai dengan positif tak terhingga. Apabila nilai RCA lebih dari satu, artinya, terdapat daya saing pada komoditas. Namun, jika nilai RCA kurang dari satu, artinya, tidak terdapat daya saing pada komoditas tersebut. Semakin besar indeks RCA, maka akan semakin tangguh.

\section{Analisis SWOT Balanced Scorecard}

Menurut Rangkuti (2011), analisis ini memuat tentang isu strategis, penyusunan formulasi strategi, tema strategi serta pemetaan strategi, serta program strategis. Langkah pertama yang dilakukan yaitu identifikasi formula strategi agar dapat menjadi tema strategis. Langkah selanjutnya, mengelompokkan strategi tersebut ke dalam isu strategis yang sudah dilakukukan dalam kegiatan analisis SWOT. Hasil pengelompokkan isu tersebut, akan terbentuk tema strategis. Dalam menentukan tema strategis, harus berpedoman pada visi dan misi dengan metode brainstorming. Selanjutnya menentukan sasaran strategis dan program strategisnya. Dalam menentukan tema strategis yang akan menjadi pedoman untuk tahun yang akan datang, dibutuhkan analisis SWOT yang komprehensif yaitu dengan cara menentukan faktor-faktor kekuatan dan kelemahan yang bersifat internal, dan juga peluang serta ancaman yang bersifat eksternal. Dalam menyusun formula strategis pada analisis SWOT yaitu dengan cara menggabungkan berbagai macam indikator yang terdapat dalam kekuatan, kelemahan, peluang, maupun ancaman. Setelah itu dapat dirumuskan progzam strategisnya.

\section{HASIL DAN PEMBAHASAN}

\section{Hasil analisis SLQ}

Terdapat sembilan jenis industri yang memiliki keunggulan komparatif di antaranya adalah industri minuman, industri pengolahan tembakau, industri tekstil, industri pakaian jadi, industri kayu, barang dari kayu dan gabus, industri pencetakan dan reproduksi media rekaman, industri farmasi, produk obat kimia, dan obat tradisional, industri furnitur dan industri lainnya. Sembilan jenis industri tersebut memiiki nilai SLQ $>1$. Dengan keunggulan komparatif yang dimiliki kesembilan jenis industri tersebut, maka jenis industri tersebut dapat di ekspor ke luar wilayah serta mampu memenuhi kebutuhan yang ada di Provinsi Jawa Tengah. 


\section{Hasil analisis DLQ}

Terdapat 23 sektor industri di Provinsi Jawa Tengah yang laju pertumbuhannya lebih cepat dibandingkan pada tingkat nasional yakni, industri makanan, industri minuman, industri pengolahan tembakau, industri tekstil, industri pakaian jadi, industri kayu, barang dari kayu dan gabus, industri kulit, barang dari kulit dan alas kaki, , industri kertas dan barang dari kertas, industri pencetakan dan reproduksi media rekaman, industri produk dari batu bara dan pengilangan minyak bumi, industri farmasi, produk obat kimia, dan obat tradisional, industri karet, barang dari karet dan plastik, industri barang galian bukan logam, industri logam dasar, industri barang logam, bukan mesin dan elektronik dan optik, industri peralatan listrik, industri mesin dan perlengkapan ytdl, industri kendaraan bermotor, trailer dan semi trailer, industri alat angkutan lainnya, industri furnitur dan industri pengolahan lainnya, serta reparasi dan pemasangan mesin dan peralatan.

\section{Hasil Analisis Gabungan SLQ dan DLQ}

Terdapat delapan industri unggulan di Provinsi Jawa Tengah yang memiliki nilai SLQ $>1$ dan DLQ>1 yakni industri industri minuman, industri pengolahan tembakau, industri tekstil, industri pakaian jadi, industri kayu, barang dari kayu, dan gabus, industri pencetakan dan reproduksi media rekaman, industri furnitur, industri pengolahan lainnya. peralatannya, industri komputer, barang

\begin{tabular}{|c|c|c|}
\hline SLQ & SLQ $>1$ & SLQ $<1$ \\
\hline DLQ>1 & \begin{tabular}{ll}
\multicolumn{2}{l}{ INDUSTRI UNGGULAN } \\
1. Industri Minuman \\
2. Industri Pengolahan \\
Tembakau \\
3. Industri Tekstil \\
4. Industri Pakaian Jadi \\
5. Industri Kayu, Barang Dari \\
Kayu, Dan Gabus \\
6. Industri Pencetakan Dan \\
7. \\
7. Industri Furnitur \\
8. Industri Pengolahan Lainnya
\end{tabular} & $\begin{array}{l}\text { INDUSTRI ANDALAN } \\
\text { 1. Industri Makanan } \\
\text { 2. Industri Kulit, Barang Dari Kulit, Dan Alas } \\
\text { Kaki } \\
\text { 3. Industri Kertas Dan Barang Dari Kertas } \\
\text { 4. Industri Produk Dari Batu Bara Dan } \\
\text { Pengilangan Minyak Bumi } \\
\text { 5. Industri Bahan Kimia Dan Barang Dari Bahan } \\
\text { Kimia } \\
\text { 6. Industri Karet, Barang Dari Karet Dan Plastik } \\
\text { 7. Industri Barang Galian Bukan Logam } \\
\text { 8. Industri Logam Dasar } \\
\text { 9. Industri Barang Logam, Bukan Mesin Dan } \\
\text { Peralatannya } \\
\text { 10. Industri Komputer, Barang Elektronik, Dan } \\
\text { Optik } \\
\text { 11. Industri Peralatan Listrik } \\
\text { 12. Industri Mesin Dan Perlengkapan Ytdl } \\
\text { 13. Industri Kendaraan Bermotor, Trailer, Dan } \\
\text { Semi Trailer } \\
\text { 14. Industri Alat Angkutan Lainnya } \\
\text { 15. Reparasi Dan Pemasangan Mesin Dan } \\
\text { Peralatan }\end{array}$ \\
\hline DLQ $<1$ & $\begin{array}{l}\text { INDUSTRI PROSPEKTIF } \\
\text { 1. Industri Farmasi, Produk Obat } \\
\text { Kimia Dan Obat Tradisional }\end{array}$ & INDUSTRI TERBELAKANG \\
\hline
\end{tabular}




\section{Hasil Analisis Shift Share}

Terdapat empat belas jenis industri di Provinsi Jawa Tengah yang memiliki keunggulan kompetitif. Jenis industri tersebut diantaranya adalah, industri minuman, industri pengolahan tembakau, industri pakaian jadi, industri kulit, barang dari kulit dan alas kaki, industri kayu, barang dari kayu, dan gabus (tidak termasuk furnitur) dan barang anyaman dari bambu, rotan dan sejenisnya, industri kertas dan barang dari kertas, industri produk dari batu bara dan pengilangan minyak bumi, industri bahan kimia dan barang dari bahan kimia, industri farmasi, produk obat kimia dan obat tradisional, industri karet dan plastik, industri komputer, barang elektronik dan optik, industri peralatan listrik, industri pengolahan lainnya, reparasi dan pemasangan mesin dan peralatan.

\section{Hasil Analisis RCA,}

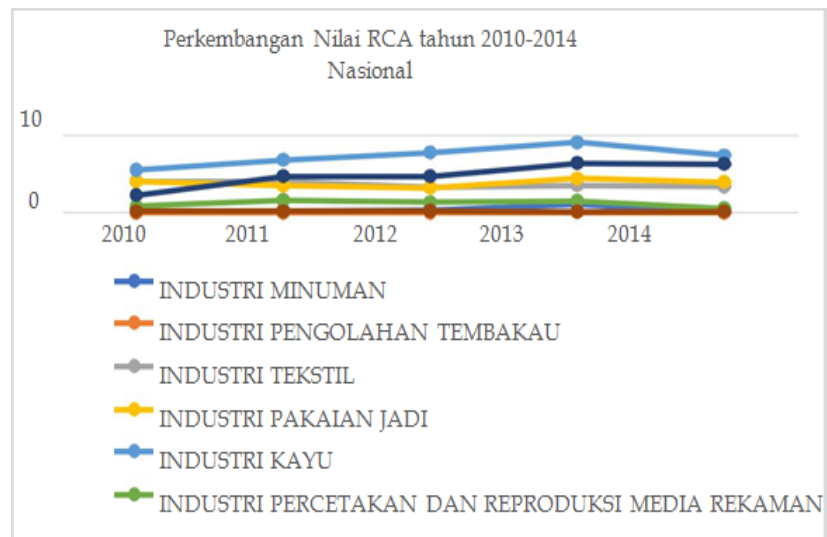

Terdapat lima jenis industri di Provinsi Jawa Tengah yang memiliki potensi daya saing di tingkat nasional yakni industri tekstil, industri pakaian jadi, industri kayu, dan industri pencetakan dan reproduksi media rekaman, serta industri furnitur.

Perkembangan Hasil Analisis RCA di Tingkat ASEAN Tahun 2010-2014

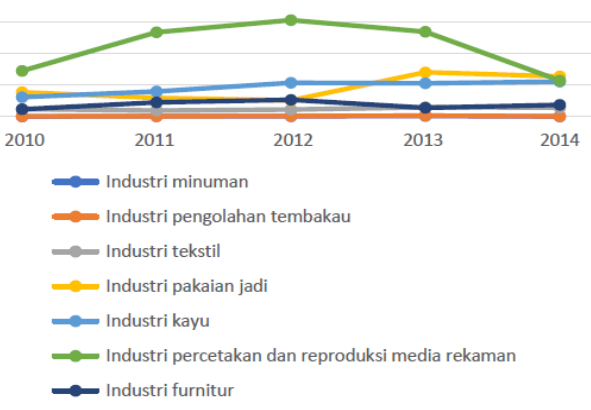

Terdapat tiga jenis industri unggulan di Provinsi Jawa Tengah yang memiliki potensi daya saing yang tinggi di tingkat ASEAN. Jenis industri tersebut diantaranya adalah industri pakaian jadi, industri kayu, serta industri pencetakan dan reproduksi media rekaman.

\section{Hasil Analisis SWOT Balanced Scorecard}

Strategi peningkatan daya saing industri unggulan dalam menghadapi MEA adalah sebagai berikut:

SO Strategy : Memperluas pangsa ekspor yang bersifat non tradisional ST Strategy : Meningkatkan kualitas produk. WO Strategy: Meningkatkan kualitas sumber daya manusia yang terampil dan dapat memenuhi permintaan pasar.

WT Strategy:Memberikan insentif kepada industri-industri yang mampu melakukan peningkatan proporsi pada bahan baku.

\begin{tabular}{lrl}
\hline \multicolumn{1}{c}{ Sasaran Strategik } & \multicolumn{1}{c}{ Inisiatif Strategik } & \multicolumn{1}{c}{ Program Strategik } \\
\hline $\begin{array}{l}\text { Shareholders value } \\
\text { S1 pertumbuhan hasil } \\
\text { keuangan }\end{array}$ & & \\
S2 pertumbuhan pendapatan & & \\
\hline $\begin{array}{l}\text { Firm Equity } \\
\text { F1 Meningkatnya penggunaan }\end{array}$ & $\begin{array}{l}\text { Peningkatan kualitas dan } \\
\text { menekan harga energi agar }\end{array}$ & $-\begin{array}{l}\text { program pengembang } \\
\text { industri }\end{array}$ \\
\hline
\end{tabular}




\begin{tabular}{|c|c|c|}
\hline Sasaran Strategik & Inisiatif Strategik & Program Strategik \\
\hline $\begin{array}{l}\text { energi pada industri yang } \\
\text { efisien } \\
\text { F2 Meningkatnya jumlah } \\
\text { investor yang melakukan } \\
\text { relokasi pada industri ke } \\
\text { Provinsi Jawa Tengah } \\
\text { F3 Produktivitas produk } \\
\text { industri }\end{array}$ & $\begin{array}{l}\text { tidak terlalu tinggi } \\
\text { - } \text { Meningkatkan jumlah tenaga } \\
\text { kerja yang terampil sesuai } \\
\text { dengan bidang industri } \\
\text { - } \\
\text { Teknologi non tradisional }\end{array}$ & $\begin{array}{l}\text { - } \text { program fasilitasi dan } \\
\text { standarisasi untuk industri } \\
\text { - } \text { program akses produk bahan } \\
\text { baku di tingkat regional dan } \\
\text { nasional } \\
\text { - } \\
\text { program pengembangan } \\
\text { energi baru }\end{array}$ \\
\hline $\begin{array}{l}\text { Organizational Capital } \\
\text { O1 Penggunaan teknologi } \\
\text { O2 Regulasi yang pro bisnis }\end{array}$ & $\begin{array}{l}\text { - Peningkatan pembelian alat- } \\
\text { alat maupun mesin-mesin } \\
\text { industri yang sesuai dengan } \\
\text { bidang industri } \\
\text { - Membuat sistem regulasi } \\
\text { yang pro bisnis }\end{array}$ & $\begin{array}{l}\text { - } \text { program peningkatan } \\
\text { pelayanan data dan informasi } \\
\text { mengenai industri } \\
\text { - } \text { program pengenalan } \\
\text { teknologi tepat guna } \\
\text { - } \text { program peningkatan sarana } \\
\text { dan prasarana } \\
\text { - } \text { program peningkatan } \\
\text { teknologi yang }\end{array}$ \\
\hline $\begin{array}{l}\text { Human Capital } \\
\text { H1 Meningkatnya } \\
\text { produktivitas tenaga kerja }\end{array}$ & $\begin{array}{l}\text { - Meningkatkan revenue tenaga } \\
\text { kerja }\end{array}$ & $\begin{array}{l}\text { - } \text { program pendidikan formal } \\
\text { dan non formal } \\
\text { - } \text { program pembinaan } \\
\text { lingkungan sosial dan } \\
\text { pemberdayaan masyarakat } \\
\text { - } \text { program pengembangan } \\
\text { sumber daya manusia } \\
\text { - } \text { program peningkatan kualitas } \\
\text { hidup dan perlindungan } \\
\text { terhadap perempuan dan } \\
\text { anak } \\
\text { - } \text { program kegiatan pendidikan } \\
\text { kemasyarakatan }\end{array}$ \\
\hline
\end{tabular}

Program peningkatan daya saing industri unggulan dalam menghadapi MEA adalah sebagai berikut: Firm Equity: Program pengembang industri, program fasilitasi dan standarisasi untuk industri, program akses produk bahan baku di tingkat regional dan nasional, program pengembangan energi baru.

Organizational Capital: Program peningkatan pelayanan data dan informasi mengenai industri, program pengenalan teknologi tepat guna, program peningkatan sarana dan prasarana, program peningkatan teknologi yang ramah lingkungan.

Human Capital: Program pendidikan formal dan non formalprogram pembinaan lingkungan sosial dan pemberdayaan masyarakat, program pengembangan sumber daya manusia, program peningkatan kualitas hidup dan perlindungan terhadap perempuan dan anak program kegiatan pendidikan kemasyarakatan. 


\section{DAFTAR PUSTAKA}

Alisjahbana, Armida S. 2014. Arah Kebijakan dan Strategi Percepatan Pengembangan Kawasan Timur Indonesia. Manado: Kementerian Perencanaan Pembangunan Nasional/ Badan Perencanaan Pembangunan Nasional.

Badan Pusat Statistik Provinsi Banten. 2015. Provinsi Banten Dalam Angka 2015. http:/ / banten.bps.go.id/index.php?hal=pu blikasi_detil\&id=21. (20 Oktober 2016).

Badan Pusat Statistik Provinsi DKI Jakarta. 2015. Provinsi DKI Jakarta Dalam Angka2015.http://jakarta.bps.go.id/index.p hp?bWVudT0xOTAwJnBhZ2U9cmFrYnVr dQ (20 Oktober 2015).

Badan Pusat Statistik Provinsi D.I. Yogyakarta. 2015. Provinsi D.I. Yogyakarta Dalam Angka 2015.

http://yogyakarta.bps.go.id/index.php?r= arc/view (20 Oktober 2016).

Badan Pusat Statistik Provinsi Jawa Barat. 2015. Provinsi Jawa Barat Dalam Angka 2015. http://jabar.bps.go.id/index.php/publikasi/44.

(20 Oktober 2016)

Badan Pusat Statistik Provinsi Jawa Tengah. 20102016. Jawa Tengah Dalam Angka 2010. Semarang: Badan Pusat Statistik Provinsi Jawa Tengah

Badan Pusat Statistik Provinsi Jawa Timur. 2015. Provinsi Jawa Timur Dalam Angka 2015. http://jatim.bps.go.id/index.php?hal=publ ikasi_detil\&id=57. (20 Oktober 2016).

Badan Pusat Statistik Republik Indonesia. 20102016. Buletin Statistik Perdagangan Luar Negeri 2010. Jakarta:

Badan Pusat Statistik Republik Indonesia.

Bank Indonesia. 2008. Profil dan Pemetaan Daya Saing Ekonomi Daerah Kabupaten/Kota di Indonesia. Jakarta: Rajawali Pers.

Burmansyah, E. 2014. Rezim Baru ASEAN: Memahami Rantai Pasokan dan Masyarakat
Ekonomi ASEAN. Yogyakarta: Pustaka Sempu.

Cahyono, Eddy. 2014. Peningkatan Daya Saing Ekonomi \& Peran Birokrasi. http:/ / ekonomi.metrotvnews.com/read/2 014/10/01/299017/peningkatandayasaing-ekonomi-peran-birokrasi (17 Oktober 2016).

DinasPerindustrian dan Perdagangan Provinsi Jawa Tengah. 2016. Rencana Strategis (Renstra) Dinas Perindustrian Dan PerdaganganProvinsi Jawa Tengah Tahun 2013-2018. Semarang: Dinas Perindustrian dan Perdagangan Provinsi Jawa Tengah

Djaafara, Rizal A., dkk. 2012. Masyarakat Ekonomi ASEAN 2015 Proses Harmonisasi di Tengah Persaingan. Jakarta: Bank Indonesia.

Domanski, dkk. 2010. MULTIPLIER EFFECTS IN LOCAL AND REGIONAL DEVELOPMENT.

Poland: Jagiellonian University

Fafurida, dkk. 2014. Strategi Pengembangan Daerah Growth Pole Melalui Pemanfaatan Potensi Lokal. Semarang: Economics \& Business Research Festival

Gupta, S. D. 2015. Comparative Advantage and Competitive Advantage: An Economics

Perspective and a Synthesis. Athens Journal of Business and Economics.

Irmawati, Setyani. 2015. Strategi Peningkatan Daya Saing Industri Unggulan Provinsi Jawa Tengah Untuk Menghadapi Asean Economic Community (Aec) 2015.Semarang: Universitas Negeri Semarang.

Kementerian Perindustrian. 2012. Laporan Kinerja Kementerian Perindustrian. Jakarta: Biro Perencanaan

Kuncoro, Mudrajad. 2007. Metode Kuantitatif Teori dan Aplikasi untuk Bisnis dan Ekonomi. Edisi Ketiga. Yogyakarta: UPP STIM YKPN.

Rangkuti, F. 2016. SWOT BALANCED SCORECARD. Jakarta: PT Gramedia Pustaka Utama. 
Salvatore, D. 1997. Ekonomi Internasional Edisi Kelima Jilid 1. (H. Munandar, Penerj.) Jakata: Erlangga.

United Nations Industrial Development Organization. 2016. Competitive Industrial Performance Index. http://www.unido.org/data1/Statistics/R esearch/cip.html. (13 Oktober 2016).

UN Comtrade Database. http://comtrade.un.org/data/ (10 November 2016).

World Economic Forum. 2016. Global Competitiveness Report 2015-2016. http:/ / reports.weforum.org/globalcompetitiveness-report-2015-2016/ economies/. (2 Oktober 2016).

World Scientific Publishing. 2014. Competitiveness Indonesia Provinces. Singapore: Lee Kuan Yew School of Public Policy. 